OPEN ACCESS

Edited by:

Ramón Sotomayor-Zárate,

University of Valparaiso, Chile

Reviewed by:

Iria Gonzalez Dopeso-Reyes,

UMR5535 Institut de Génétique

Moléculaire de Montpellier (IGMM),

France

Mario Rivera-Meza,

University of Chile, Chile

*Correspondence:

Hector E. Yarur

heyarur@uc.cl

Katia Gysling

kgysling@bio.puc.cl

Specialty section: This article was submitted to

Neuropharmacology,

a section of the journal

Frontiers in Pharmacology

Received: 25 July 2019 Accepted: 20 November 2019

Published: 08 January 2020

Citation:

Yarur HE, Andrés ME and Gysling K (2020) Type $2 \beta$ Corticotrophin

Releasing Factor Receptor Forms a

Heteromeric Complex With Dopamine

D1 Receptor in Living Cells.

Front. Pharmacol. 10:1501.

doi: 10.3389/fphar.2019.01501

\section{Type $2 \beta$ Corticotrophin Releasing Factor Receptor Forms a Heteromeric Complex With Dopamine D1 Receptor in Living Cells}

\author{
Hector E. Yarur ${ }^{*}$, Maria Estela Andrés and Katia Gysling * \\ Department of Cellular and Molecular Biology, Faculty of Biological Sciences, Pontificia Universidad Católica de Chile, \\ Santiago, Chile
}

Corticotrophin releasing factor (CRF) and its related peptides differentially bind to CRF receptors to modulate stress-related behaviors. CRF receptors comprise two G-protein coupled receptors (GPCR), type-1 CRF receptors (CRF1), and type-2 CRF receptors (CRF2). CRF2 encompasses three spliced variants in humans, alpha (CRF2 $\alpha$ ), beta (CRF2 $\beta$ ), and gamma (CRF2 $\gamma$ ), which differ in their N-terminal extracellular domains and expression patterns. Previously, we showed that CRF2 $\alpha$ form a heteromeric protein complex with dopamine D1 receptors (D1R), leading to changes in the signaling of D1R. Based on the high sequence identity between CRF2 $\alpha$ and CRF2 $\beta$, we hypothesized that CRF2 $\beta$ also heteromerize with D1R. To test the hypothesis, we compared the expression and localization of both CRF2 isoforms and whether CRF2 $\beta$ form stable protein complexes with D1R in HEK293 and ATR75 cell lines. We observed that the immunoreactivity for CRF2 $\beta$ was similar to that of CRF2 $\alpha$ in the endoplasmic compartment but significantly higher in the Golgi compartment. Immunoprecipitation analysis showed that CRF2 $\beta$ forms a heteromeric protein complex with D1R. Furthermore, the protein complex formed by CRF2 $\beta$ and D1R was stable enough to change the sub-cellular localization of CRF2 $\beta$ when it was co-expressed with a construct of D1R bearing a nuclear localization signal. Immunofluorescence in A7R5 cells, which endogenously express CRF2 $\beta$ and D1R, shows significant colocalization of CRF2 $\beta$ with D1R. In conclusion, our results show that CRF2 $\beta$ forms a stable heteromeric protein complex with $\mathrm{D} 1 \mathrm{R}$, a potential new therapeutic target in tissues where both receptors are co-expressed, such as the septum in the brain, and heart, kidney, and skeletal muscle in the periphery.

Keywords: D1R (dopamine D1 receptor), heteromer, GPCR (G protein-coupled receptors, A7r5 cells, CRF2 $\beta$

\section{INTRODUCTION}

Corticotrophin releasing factor (CRF) constitutes a key component in the animal stress response (Vale et al., 1981; Snyder et al., 2015). The CRF system has three additional peptides, urocortin (UCN) 1, UCN2, and UCN3 (Hillhouse and Grammatopoulos, 2006). CRF peptides signal through two Gprotein coupled receptors (GPCR), type-1 (CRF1) and type-2 (CRF2) receptors (Dautzenberg and 
Hauger, 2002). CRF1 and CRF2 receptors have high amino acid sequence identity but a distinct affinity for CRF peptides (Chalmers et al., 1996). CRF has a higher affinity for CRF1 than for CRF2, (Rutz et al., 2006; Deussing and Chen, 2018). UCN1 has higher affinity than CRF for CRF1 and CRF2, while UCN2 and UCN3 are highly selective for CRF2 (De Souza, 1995).

Three splice variants of CRF2 $(\alpha, \beta$, and $\gamma)$ are expressed in several human tissues (Lovenberg et al., 1995a; Kostich et al., 1998). In rodents and humans, the CRF $2 \alpha$ splice variant presents a high density in the central nervous system, and the CRF2 $\beta$ splice variant is primarily expressed in peripheral tissue (Lovenberg et al., 1995b; Perrin et al., 1995). In humans, CRF2 $\beta$ is present in some brain regions and peripheral tissues (Kostich et al., 1998). CRF2 splice variants differ only in their $\mathrm{N}$ terminal extracellular domains, which confer significant differences in their sub-cellular localization (Schulz et al., 2010; Teichmann et al., 2012; Slater et al., 2016a). It has been described that CRF and dopamine (DA) signaling contributes to responses, such as stress-related response (Orozco-Cabal et al., 2008). Thus, the understanding of the mechanisms by which DA and CRF interact could lead to reveal the mechanisms by which these neurotransmitters modulate the behavioral response.

We and other groups have shown that CRF receptors form heteromers with other GPCRs (Fuenzalida et al., 2014; Navarro et al., 2015; Hasdemir et al., 2017). Particularly, the CRF2 $\beta$ isoform assembles into heteromeric complexes with CRF1 (Hasdemir et al., 2017) and the CRF2 $\alpha$ isoform assembles with the dopamine D1 receptor (D1R, Fuenzalida et al., 2014). CRF2 $\alpha / D 1 R$ heteromer displays distinct signaling properties than D1R and CRF2 $\alpha$ alone (Fuenzalida et al., 2014).

Since CRF $2 \alpha$ and CRF2 $\beta$ share a high protein sequence similarity and CRF2 $\alpha$ can interact with D1R, we decided to study whether CRF2 $\beta$ forms also a stable heteromeric complex with D1R. To this end, we first compared the sub-cellular localization of recombinant CRF $2 \alpha$ and CRF $2 \beta$ expressed in HEK293 cells. Next, we studied if CRF2 $\beta$ can form a stable protein complex with D1R. To this end we used the strategy designed by O'Dowd et al. (2005) consisting in: a) the addition of a nuclear localization signal (nls) to D1R (D1Rnls) that translocate the receptor and its eventual partner CRf2o the nucleus and $b$ ) the use of butaclamol, a reverse agonist of D1R that retains D1Rnls and its partner in the plasmatic membrane. We also evaluated the degree of colocalization between D1R and CRF2 $\beta$ in the A7R 5 cell line, derived from vascular smooth muscle, that has been shown to express D1R (Chen et al., 2018) and CRF2 $\beta$ (Kageyama et al., 2000; Hoare et al., 2005). Our results show, that CRF2 $\beta$ can form a stable protein complex with $\mathrm{D} 1 \mathrm{R}$ and that both receptors are significantly colocalized in A7R5 cells.

\section{MATERIAL AND METHODS}

\section{Cell Culture and Transfection}

HEK293T cells and A7R5 cells (kindly donated by Dr. Mario Chiong, University of Chile) were grown with DMEM (Gibco) supplemented with 10\% FBS (HyClone Labs), 1\% penicillin/ streptomycin 100× (Gibco), and $2 \mathrm{mM}$ GlutaMax (Gibco). Plasmids were transfected using Lipofectamine 2000 (Invitrogen) according to the manufacturer's instructions and as previously described (Fuenzalida et al., 2014). Experiments were performed $48 \mathrm{~h}$ after plasmids transfection. The ratio of transfected plasmid was 1:1 and the amount of DNA transfected for immunofluorescence was $500 \mathrm{ng}$ of total DNA and for immunoprecipitation experiments was 8 ug of total DNA.

\section{Expression Vectors}

pcDNA3.1/Myc-His/D1R, pcDNA3.1/myc-His/D1Rnls, and pcDNA3.1/HA-CRF2 $\alpha$ were previously described (Fuenzalida et al., 2014; Slater et al., 2016b). The pcDNA3.1/HA-CRF2 $\beta$ was commercially obtained (GeneCopoeia). The HA epitope in both receptors is located in their $\mathrm{N}$ terminal.

\section{Protein Extraction and Immunoprecipitation}

After treatments, HEK293T cells were collected in ice-cold PBS ( $\mathrm{pH} 7.4$ ), centrifuged at $1500 \mathrm{rpm}$ for $5 \mathrm{~min}$ and resuspended in lysis buffer (50 mM Tris- $\mathrm{HCl}, \mathrm{pH} 8.0,150 \mathrm{mM} \mathrm{NaCl}, 1 \mathrm{mM}$ EDTA, $0.1 \%$ SDS, and $1 \%$ Triton X-100) with the Protease Inhibitor Cocktail cOmplete Mini (Roche) as described by Rutz et al. (2006). Cells were then homogenized with three pulses of $10 \mathrm{~s}$ using a piston sonicator (Cell Ultrasonic Disrupter) and incubated for at least $1 \mathrm{~h}$ at $4^{\circ} \mathrm{C}$. Finally, the homogenate was centrifuged at $15,000 \mathrm{rpm}$ for $15 \mathrm{~min}$ at $4^{\circ} \mathrm{C}$. The supernatant was collected, and protein concentration determined with the Micro BCA Protein Assay Kit (Thermo Scientific). Co-immunoprecipitation assays were performed essentially as previously described (Fuenzalida et al., 2014). Seven hundred $\mu$ g of protein extract were pre-cleared with TrueBlot ${ }^{\circledR}$ anti-Rabbit Ig IP Agarose Beads (Rockland) and incubated with $1 \mu \mathrm{g}$ of rabbit anti-Myc antibody (Ab9106, Abcam). Loading buffer $2 \times(8 \mathrm{M}$ urea, 2\% SDS, $100 \mathrm{mM}$ DTT, $375 \mathrm{mM}$ Tris, $\mathrm{pH}$ 6.8) was added to each sample and heated to $37^{\circ} \mathrm{C}$ for $1 \mathrm{~h}$ to perform western blotting.

\section{Western Blotting}

Proteins were fractionated in $10 \%$ sodium dodecyl sulfatepolyacrylamide gel electrophoresis (SDS-PAGE) and then transferred into PVDF membrane (Millipore). Membranes were incubated overnight at $4^{\circ} \mathrm{C}$ with mouse anti-HA (1:1000, \#901501, BioLegend) followed by the peroxidase-conjugated anti-mouse antibody for $2 \mathrm{~h}$ (1/4000, Jackson ImmunoResearch Laboratories). The membranes were revealed using SuperSignal West Pico Chemiluminescent Substrate (Pierce Biotechnology).

\section{Heteromer Mobilization Assay}

HEK293T cells were seeded at a density of $7 \times 10^{6}$ cells per well on a 24-well plate on coverslips coated with poly-L-lysine (Sigma). Six hours post-transfection, the cells were treated with $1 \mu \mathrm{M}(+)$-butaclamol (D1R antagonist) in supplemented DMEM medium for $48 \mathrm{~h}$ (O'Dowd et al., 2005). After washing with PBS, cells were fixed with $4 \%$ paraformaldehyde (PFA) and receptors localization analyzed by immunofluorescence. 


\section{Immunofluorescence and Confocal Microscopy}

Immunofluorescence assays were done as previously described (Fuenzalida et al., 2014). Cells were incubated with primary antibodies: rabbit anti-D1R (1:500; sc-14001, Santa Cruz Biotechnology), goat anti-CRF2 (1:500; sc-20550, Santa Cruz Biotechnology), mouse anti-HA (1:1000; HA.11 Clone 16B12, Covance Inc), rat anti-KDEL (1:500; ab50601, Abcam); rabbit anti-D1R receptor (1:500; ab20066, Abcam), and rabbit antiGiantin (1:500; ab80864, Abcam) overnight at $4^{\circ} \mathrm{C}$ in a wetchamber. Cells were then washed and incubated for $2 \mathrm{~h}$ with the following secondary antibodies: donkey anti-rabbit AlexaFluor $^{488}$, donkey anti-rabbit AlexaFluor ${ }^{\mathrm{Cy} 3}$, donkey antigoat AlexaFluor ${ }^{488}$, donkey anti-goat AlexaFluor ${ }^{\mathrm{Cy} 3}$, and donkey anti-rat AlexaFluor $^{647}$ at room temperature. Cells were washed and mounted with mounting media (Dako).

Images were obtained with a confocal microscope (Fluoview 1000, Olympus) And Fluoview V6.0 software. images were digitally obtained with a $100 \times$ objective (N.A. 1.4 Oil). The stacking of images was done with A Z step of $200 \mathrm{Nm}$ per cell. Images were processed using the imagej software (Rsb.Info.Nih.Gov/Ij). The deconvolution analysis was performed using the "Iterative Deconvolve 3D" plugin within imagej as previously described (Blanco et al., 2011) and Manders coefficient And Van Steensel analysis was used for measure colocalization (Manders et al., 1993; Van Steensel et al., 1996). Fluorescence Intensity was used to compare the cellular distribution of the marks.

\section{Statistical Analysis}

Statistical analysis was performed with the GraphPad Prism 6 software (GraphPad Software). The data are expressed as the mean \pm SEM. Statistical significance was assessed with unpaired Mann-Whitney $U$ test.

\section{RESULTS}

\section{Subcellular Localization of CRF2 Isoforms Expressed in HEK293 Cells}

The residence time of GPCR in each compartment of the secretory path varies according to their protein sequence that determines specific protein-protein interactions (Chuang and Sung, 1998). To determine the localization of each CRF receptor, we used specific markers for each secretory compartment, KDEL for the endoplasmic reticular compartment, and Giantin for the Golgi compartment (Figure 1). As can be seen in Figure 1,
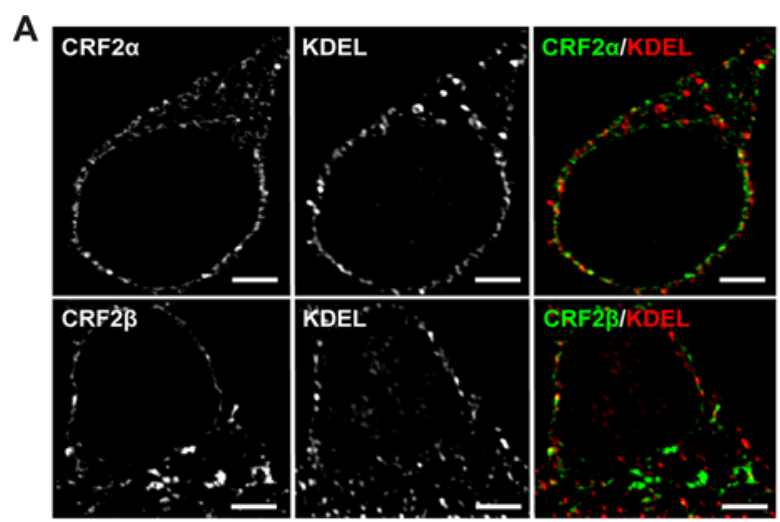

\section{C}
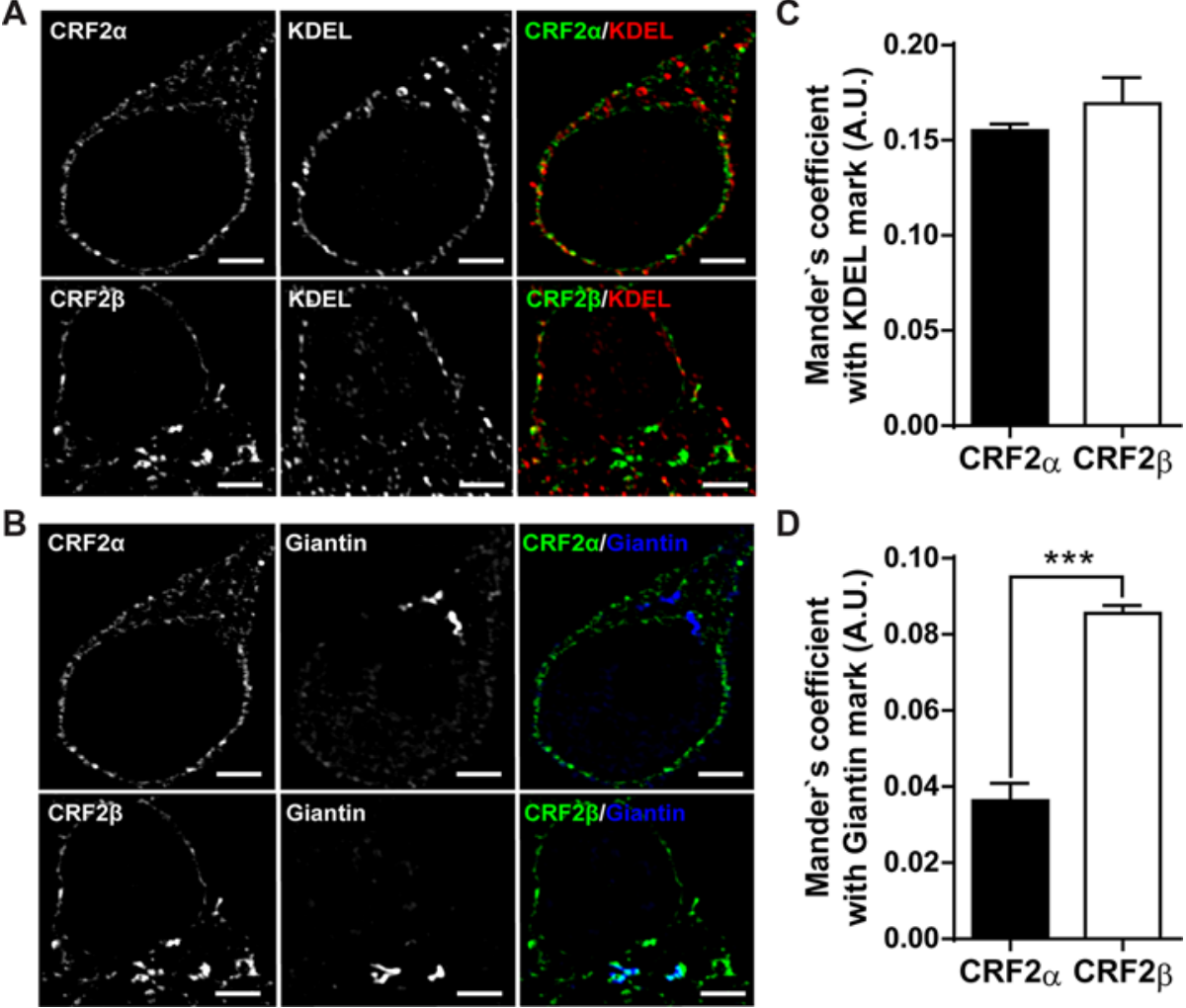

FIGURE 1 | Comparison of the subcellular distribution of CRF2 isoforms in HEK293 cells. (A and B) Confocal immunodetection of the CRF2 isoforms in a preparation of HEK293 cells (one-plane microphotographs). (A) Confocal immunofluorescence for CRF2 $\alpha$ or CRF2 $\beta$ (green), using a mouse anti-HA antibody and KDEL (red) (scale bar: $2 \mu \mathrm{m}$ ). (B) Confocal immunofluorescence for CRF2 $\alpha$ or CRF2 $\beta$ (green) and Giantin (blue) (scale bar: $2 \mu \mathrm{m})$. (C) Mander's analyses for colocalization in A. (D) Mander's analyses for co-localization in B. Unpaired Mann-Whitney $U$ test compared between CRF2 isoforms ( $\left.{ }^{\star \star \star} p<0.0005\right)$. Values are expressed as mean \pm SEM, $\mathrm{N}=3$ and each $\mathrm{N}$ represent 7 independent cells analyzed. 
CRF2 $\alpha$ is mostly associated with the KDEL compartment (Figures 1 A, B), as previously shown (Fuenzalida et al., 2014). The presence of CRF $2 \beta$ in the KDEL compartment was similar to CRF2 $\alpha$ (Figures 1A, C). In contrast, the presence of CRF2 $\beta$ in the Giantin compartment was significantly higher than that of CRF2 $\alpha$ (Figures 1B, D). Overall, these results indicate that the presence of CRF2 $\beta$ in the secretory pathway is significantly higher than CRF2 $\alpha$.

\section{CRF2 $\beta$ Forms a Protein Complex With D1R}

To determine if CRF2 $\beta$ form a protein complex with D1R, we performed co-immunoprecipitation experiments using whole extracts obtained from HEK293 cells transfected with plasmids bearing human HA-CRF $2 \beta$ and Myc-D1R. HA-CRF2 $\beta$ (band of $\sim 70 \mathrm{kDa}$ ) precipitated in the same immunocomplex with Myc$\mathrm{D} 1 \mathrm{R}$ in protein extracts from cells transiently transfected with both receptors (Figure 2). The specificity of this interaction is shown by control experiments in which immunoreactivity is not observed when the immunoprecipitations were performed with protein extracts from cells transfected with HA-CRF2 $\beta$ alone or with the empty vectors.

To evaluate the stability of the protein complex formed between CRF2 $\beta$ and D1R, we used the heteromer mobilization strategy described by O'Dowd et al. (2005). Through the use of immunofluorescence, we observed that CRF2 $\beta$ and D1R co-

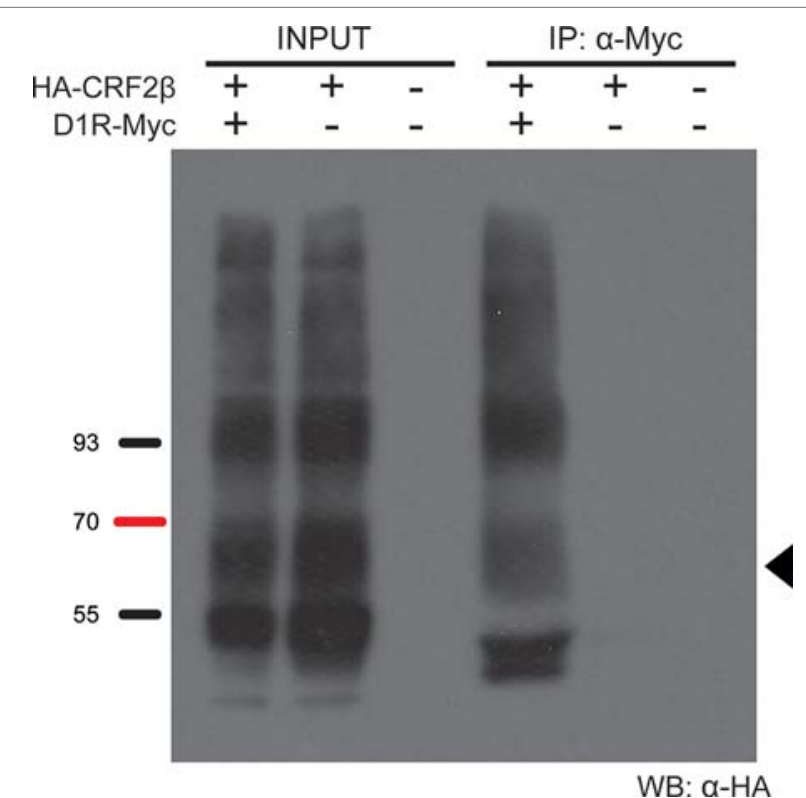

FIGURE 2 | D1R and CRF2 $\beta$ form a protein complex in HEK293 cells. Representative western blot of the co-immunoprecipitation of D1R and CRF2 $\beta$ from HEK293 cells. The protein extract from HEK293 cells expressing CRF2 $\beta$ plus D1R, CRF2 $\beta$, or empty vector pcDNA were incubated with a rabbit anti-myc antibody for the immunoprecipitation and with a mouse anti$\mathrm{HA}$ antibody for the immunoreactivity for CRF2 $\beta$. The black arrow shows the estimated molecular weight for CRF2 $\beta(\sim 70 \mathrm{kDa})$. The image was a representation of three replicated experiments. Input line is $5 \%$ of the whole protein extraction and IP line is the immunoprecipitation of the protein of interest from the whole protein extraction. localize in intracellular compartments (Figure 3). Interestingly, the incubation with $1 \mu \mathrm{M}$ butaclamol (BTC), specific D1R antagonist, changed the subcellular distribution of CRF2 $\beta$ from a central localization to an out of the center localization in HEK293 cells (Figures 3A, B) supporting the formation of a stable protein complex between the receptors.

To further test the interaction and stability of the complex between D1R and CRF2 $\beta$, we studied the localization of CRF2 $\beta$ when it is co-expressed with a mutant recombinant $\mathrm{D} 1 \mathrm{R}$ that bears a nls (Figures 3C, D). We detected a more pronounced colocalization of the CRF2 $\beta$ with D1Rnls (Figure 3). The formation of a stable protein complex was further proven using HEK293 cells co-expressing D1Rnls and CRF2 $\beta$ in the presence of BTC. The presence of BTC modified the cellular distribution of CRF2 $\beta$, from a central location to a peripheral localization (Figures 3C, D). Taken together, the data show that CRF $2 \beta$ forms a stable protein complex with $D 1 R$ in HEK293 cells.

\section{In Vivo Visualization of the CRF2 $\beta$ and D1R Heteromer Complex in A7R5 Cells}

The previous data showing that recombinant CRF $2 \beta$ and $D 1 R$ form a stable protein complex, prompted us to test whether endogenous proteins heteromerize. To this end, we used A7R5 cells derived from vascular smooth muscle cells from rat thoracic aorta that express both receptors (Hoare et al., 2005; Chen et al., 2018). Using immunofluorescence, we corroborated the expression of both CRF2 $\beta$ and D1R in A7R5 cells, which colocalize in these cells (Figure 4A). To quantify the extent of colocalization, we applied the method of Van Steensel et al. (1996). As can be seen in Figure 4B, the quantitative analysis of CRF2 $\beta$ and D1R labels yielded a "bell shape" curve indicating colocalization, with a colocalization index of $0.140 \pm 0.006$ (Figure 4B).

\section{DISCUSSION}

In the present study, we show that CRF $2 \beta$ differs in its subcellular localization pattern with CRF2 $\alpha$, but also form a stable protein complex with D1R. CRF $2 \alpha$ and CRF $2 \beta$ were found mainly in the endoplasmic reticulum; however, CRF $2 \beta$ was associated with the Golgi apparatus in a significantly higher amount than CRF $2 \alpha$. Interestingly, equal to CRF $2 \alpha$, CRF $2 \beta$ can form a stable protein complex with D1R.

CRF2 $\beta$ was found mainly associated with the endoplasmic reticulum; similar to what it has been previously reported for CRF2 $\alpha$ (Slater et al., 2016b). However, CRF2 $\beta$ displays a higher association than CRF $2 \alpha$ to the Golgi apparatus. Previously, it was reported that overexpressed CRF $2 \beta$ localizes in the plasma membrane of HEK293 cells (Markovic et al., 2008). Our immunofluorescent assays with overexpressed CRF2 $\alpha$ and CRF2 $\beta$ in HEK293 cells unequivocally show that the labeling is mainly associated with the endoplasmic reticulum for both CRF $2 \alpha$ and CRF2 $\beta$, although CRF2 $\beta$ is also associated with the Golgi compartment. 

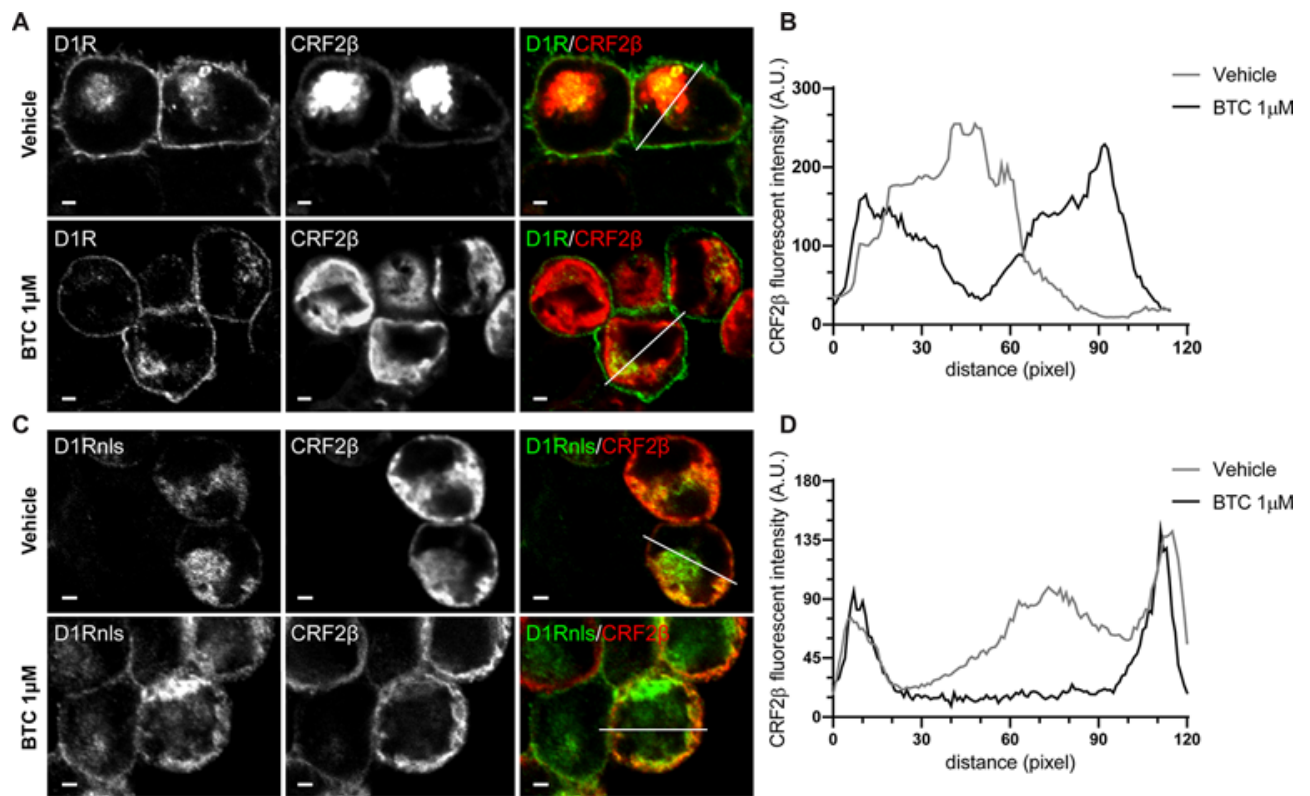

FIGURE 3 | The protein complex of D1R and CRF2 $\beta$ is stable to change their cellular localization. (A and C) Confocal immunodetection of the CRF2 $\beta$ and D1R or D1Rnls in the presence of $1 \mu \mathrm{M}$ of Butaclamol (BTC) in HEK293 cells. (A) Confocal immunofluorescence for CRF2 $\beta$ (red), using a mouse anti-HA antibody and D1R (green) in the presence of BTC or vehicle (scale bar: $2 \mu \mathrm{m}$ ). (C) Confocal immunofluorescence for CRF2 $\beta$ (red) and D1Rnls (green) in the presence of BTC or vehicle (scale bar: $2 \mu \mathrm{m}$ ). (B) Quantification of the distribution of CRF2 $\beta$ fluorescence in A. (D) Quantification of the distribution of CRF2 $\beta$ fluorescence in C. White lines depict the zone where CRF2 $\beta$ fluorescence was quantified.
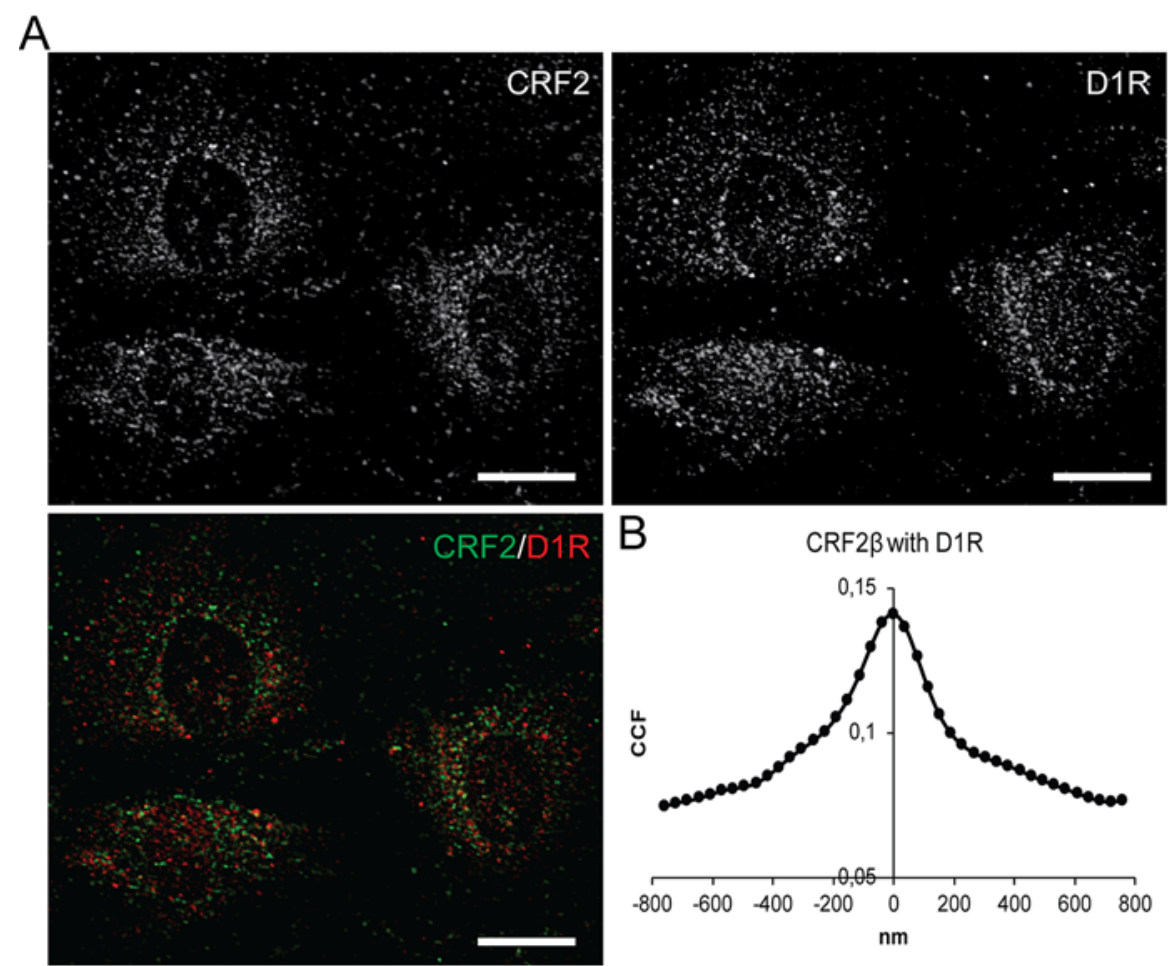

FIGURE 4 | CRF2 $\beta$ and D1R are endogenously express in A7R5 cells and present significant colocalization. (A) Confocal immunodetection of CRF2 $\beta$ and D1R in A7R5 cells. (A) Confocal immunofluorescence for CRF2 3 (green) and D1R (red) (scale bar: $20 \mu \mathrm{m}$ ). (B) Quantification of the colocalization of CRF2 $\beta$ with D1R by Van Steensel analysis. 
CRF2 $\alpha$, but not CRF2 $\beta$, has a non-cleavable pseudo signal peptide in the $\mathrm{N}$-terminal that allows the formation of a protein complex with calnexin, an integral protein of the endoplasmic reticulum (Rutz et al., 2006; Schulz et al., 2010). Thus, it is possible that the difference in the $\mathrm{N}$-terminals between both CRF2 isoforms could be responsible for the differences in their subcellular localization.

Different experimental approaches support that CRF2 $\beta$ forms a protein complex with D1R, like CRF2 $\alpha$ (Fuenzalida et al., 2014). First, co-immunoprecipitation assays of recombinant proteins showed that CRF2 $\beta$ and D1R are in the same immunocomplex. Second, the use of the heteromer mobilization assay described by O'Dowd et al. (2005), allowed us to show that CRF2 $\beta$ follows the cellular distribution of D1Rnls, indicative of a stable protein complex. The stability of the protein complex is relevant for cellular functions such as signaling and endocytosis, among others (Tohgo et al., 2003).

The interaction between GPCRs is not required for ligand recognition or signaling, but may affect receptor mobilization and/or intracellular trafficking (Lohse, 2010). The formation of a heteromeric complex could change some of the GPCR properties such as the ligand affinity, intracellular signaling, desensitization, and recycling properties of the single receptors that compose the heteromeric complex. Several examples of these changes have been published (Juhasz et al., 2008; Magalhaes et al., 2010; Navarro et al., 2015). The presence of GPCRs mainly in intracellular compartments has been described before (Magalhaes et al., 2010; Chow et al., 2012). This subcellular localization of GPCRs is relevant for the assembly of a protein complex between them (Margeta-Mitrovic et al., 2000; Magalhaes et al., 2010). Further studies should evaluate how the difference in the subcellular localization between CRF $2 \alpha$ and CRF2 $\beta$ impacts in their heteromerization with D1R, and how the presence of ligands influences in their assembly or disassembly with D1R (O'Dowd et al., 2011). The high identity in amino acid sequence that share both CRF2 receptors allow suggesting that a common domain could be responsible for the interaction of CRF2 with D1R.

The functional implications of the interaction between CRF2 $\beta$ and D1R could involve modulation of their actions in brain regions such as the septum and hippocampus, where both receptors are co-expressed and various peripheral areas such as the renal system and/or the blood circulatory system (Jose et al., 1998; Takahashi, 2012). Interestingly, the expression of both

\section{REFERENCES}

Armando, I., Villar, V. A., and Jose, P. A. (2011). Dopamine and renal function and blood pressure regulation. Comp. Physiol. 1, 1075-1117. doi: 10.1002/ cphy.c100032

Blanco, E. H., Zúñiga, J. P., Andrés, M. E., Alvarez, A. R., and Gysling, K. (2011). Corticotropin-releasing factor binding protein enters the regulated secretory pathway in neuroendocrine cells and cortical neurons. Neuropeptides 45, $273-$ 279. doi: 10.1016/j.npep.2011.05.002

Chalmers, D. T., Lovenberg, T. W., Grigoriadis, D. E., Behan, D. P., and De Souza, E. B. (1996). Corticotrophin-releasing factor receptors: from molecular biology to drug design. Trends Pharmacol. Sci. 17, 166-172. doi: 10.1016/0165-6147 (96)81594-X
CRF2 $\beta$ and D1R is well documented in the kidney and the heart (Seeman and Grigoriadis, 1987; Yamaguchi et al., 1993; Ozono et al., 1997; Tezval et al., 2009; Takahashi, 2012). Dopamine controls ion transport and inflammatory response in the kidney (Armando et al., 2011) and even though the role of CRF2 $\beta$ is still not understood, it has been proposed that it could be implicated in vascular relaxation on renal arteries (Sanz et al., 2003). It has not been shown the presence of the D1R/CRF2beta complex in human cells. However, the presence of both receptors in the same cells in human kidney and heart tissue gives anatomical support for their eventual heteromerization.

In summary, the formation of a CRF $2 \beta$ and $\mathrm{D} 1 \mathrm{R}$ protein complex may be therefore a potential therapeutic target for some brain disorders as well as cardiovascular or renal diseases. Thus, our data provide a new molecular target with new potential pharmacological properties.

\section{DATA AVAILABILITY STATEMENT}

The datasets generated for this study are available on request to the corresponding author.

\section{AUTHOR CONTRIBUTIONS}

HY, MA, and KG designed the experiments. HY performed the experiments and wrote the manuscript. HY, MA, and KG edited the manuscript.

\section{FUNDING}

This work was funded by FONDECYT grants No 1150244 and 1191274 from CONICYT. HY was recipient of a doctoral fellowship from CONICYT.

\section{ACKNOWLEDGMENTS}

We thank Dr. Mario Chiong, Universidad de Chile, for giving us access to the A7R5 cells and for his insightful comments on how to work with them.

Chen, J., Shi, S., Cai, X., Li, H., Wang, L., Li, H., et al. (2018). DR1 activation reduces the proliferation of vascular smooth muscle cells by JNK/c-Jun dependent increasing of Prx3. Mol. Cell Biochem. 440 (1-2), 157-165. doi: 10.1007/s11010-017-3164-0

Chow, K. B., Sun, J., Chu, K. M., Tai Cheung, W., Cheng, C. H., and Wise, H. (2012). The truncated ghrelin receptor polypeptide (GHS-R1b) is localized in the endoplasmic reticulum where it forms heterodimers with ghrelin receptors (GHS-R1a) to attenuate their cell surface expression. Mol. Cell Endocrinol. 348, 247-254. doi: 10.1016/j.mce.2011.08.034

Chuang, J. Z., and Sung, C. H. (1998). The cytoplasmic tail of rhodopsin acts as a novel apical sorting signal in polarized MDCK cells. J. Cell Biol. 142 (5), $1245-$ 1256. doi: $10.1083 /$ jcb.142.51245 
Dautzenberg, F. M., and Hauger, R. L. (2002). The CRF peptide family and their receptors: yet more partners discovered. Trends Pharmacol. Sci. 23, 71-77. doi: 10.1016/S0165-6147(02)01946-6

De Souza, E. B. (1995). Corticotropin-releasing factor receptors: physiology, pharmacology, biochemistry and role in central nervous system and immune disorders. Psychoneuroendocrinology 20, 789-819. doi: 10.1016/0306-4530(95) 00011-9

Deussing, J. M., and Chen, A. (2018). The Corticotropin-Releasing Factor Family: physiology of the stress response. Physiol. Rev. 98, 2225-2286. doi: 10.1152/ physrev.000422017

Fuenzalida, J., Galaz, P., Araya, K. A., Slater, P. G., Blanco, E. H., Campusano, J. M., et al. (2014). Dopamine D1 and corticotrophin-releasing hormone type- $2 \alpha$ receptors assemble into functionally interacting complexes in living cells. $\mathrm{Br}$. J. Pharmacol. 171, 5650-5664. doi: 10.1111/bph.12868

Hasdemir, B., Mahajan, S., Oses-Prieto, J., Chand, S., Woolley, M., Burlingame, A., et al. (2017). Actin cytoskeleton-dependent regulation of corticotropinreleasing factor receptor heteromers. Mol. Biol. Cell. 28, 2386-2399. doi: 10.1091/mbc.e16-11-0778

Hillhouse, E. W., and Grammatopoulos, D. K. (2006). The molecular mechanisms underlying the regulation of the biological activity of corticotropin-releasing hormone receptors: implications for physiology and pathophysiology. Endocr. Rev. 27, 260-286. doi: 10.1210/er.2005-0034

Hoare, S. R., Sullivan, S. K., Fan, J., Khongsaly, K., and Grigoriadis, D. E. (2005). Peptide ligand binding properties of the corticotropin-releasing factor (CRF) type 2 receptor: pharmacology of endogenously expressed receptors, G-protein-coupling sensitivity and determinants of CRF2 receptor selectivity. Peptides. 26, 457-470. doi: 10.1016/j.peptides.2004.10.019

Jose, P. A., Eisner, G. M., and Felder, R. A. (1998). Renal dopamine receptors in health and hypertension. Pharmacol. Ther. 80, 149-182. doi: 10.1016/S01637258(98)00027-8

Juhasz, J. R., Hasbi, A., Rashid, A. J., So, C. H., George, S. R., and O’Dowd, B. F. (2008). Mu-opioid receptor heterooligomer formation with the dopamine D1 receptor as directly visualized in living cells. Eur. J. Pharmacol. 581, 235-243. doi: 10.1016/j.ejphar.2007.11.060

Kageyama, K., Gaudriault, G. E., Bradbury, M. J., and Vale, W. W. (2000). Regulation of corticotropin-releasing factor receptor type $2 \mathrm{~b}$ messenger ribonucleic acid in the rat cardiovascular system by urocortin, glucocorticoids, and cytokines. Endocrinol. 141, 2285-2293. doi: 10.1210/endo.141.77572

Kostich, W. A., Chen, A., Sperle, K., and Largent, B. L. (1998). Molecular identification and analysis of a novel human corticotropin-releasing factor (CRF) receptor: the CRF2gamma receptor. Mol. Endocrinol. 12, 1077-1085. doi: $10.1210 /$ mend.12.80145

Lohse, M. J. (2010). Dimerization in GPCR mobility and signaling. Curr. Opin. Pharmacol. 10, 53-58. doi: 10.1016/j.coph.2009.10.007

Lovenberg, T. W., Chalmers, D. T., Liu, C., and De Souza, E. B. (1995b). CRF2 alpha and CRF2 beta receptor mRNAs are differentially distributed between the rat central nervous system and peripheral tissues. Endocrinology 136, 41394142. doi: 10.1210/endo.136.9.7544278

Lovenberg, T. W., Liaw, C. W., Grigoriadis, D. E., Clevenger., W., Chalmers, D. T., De Souza, E. B., et al. (1995a). Cloning and characterization of a functionally distinct corticotropin-releasing factor receptor subtype from rat brain. Proc. Natl. Acad. Sci. U. S. A. 92, 5759. doi: 10.1073/pnas.92.3.836

Magalhaes, A. C., Holmes, K. D., Dale, L. B., Comps-Agrar, L., Lee, D., Yadav, P. N., et al. (2010). CRF receptor 1 regulates anxiety behavior via sensitization of 5-HT2 receptor signaling. Nat. Neurosci. 13, 622-629. doi: $10.1038 / \mathrm{nn} 2529$

Manders, E. M., Verbeek, F. J., and Aten, J. A. (1993). Measurement of colocalization of objects in dual-colour confocal images. J. Microsc. 169, 375-382. doi: 10.1111/j.1365-2818.1993.tb03313.x

Margeta-Mitrovic, M., Jan, Y. N., and Jan, L. Y. (2000). A trafficking checkpoint controls GABA(B) receptor heterodimerization. Neuron 27, 97-106. doi: 10.1016/S0896-6273(00)00012-X

Markovic, D., Punn, A., Lehnert, H., and Grammatopoulos, D. K. (2008). Intracellular mechanisms regulating corticotropin-releasing hormone receptor-2beta endocytosis and interaction with extracellularly regulated kinase $1 / 2$ and p38 mitogen-activated protein kinase signaling cascades. Mol. Endocrinol. 22, 689-706. doi: 10.1210/me.2007-0136
Navarro, G., Quiroz, C., Moreno-Delgado, D., Sierakowiak, A., McDowell, K., Moreno, E., et al. (2015). Orexin-corticotropin-releasing factor receptor heteromers in the ventral tegmental area as targets for cocaine. J. Neurosci. 35, 6639-6653. doi: 10.1523/JNEUROSCI.4364-142015

O’Dowd, B. F., Ji, X., Alijaniaram, M., Rajaram, R. D., Kong, M. M., Rashid, A., et al. (2005). Dopamine receptor oligomerization visualized in living cells. J. Biol. Chem. 280, 37225-37235. doi: 10.1074/jbc.M504562200

O'Dowd, B. F., Ji, X., Alijaniaram, M., Nguyen, T., and George, S. R. (2011) Separation and reformation of cell surface dopamine receptor oligomers visualized in cells. Eur. J. Pharmacol. 658, 74-83. doi: 10.1016/ j.ejphar.2011.02.030

Orozco-Cabal, L., Liu, J., Pollandt, S., Schmidt, K., Shinnick-Gallagher, P., and Gallagher, J. P. (2008). Dopamine and corticotropin-releasing factor synergistically alter basolateral amygdala-to-medial prefrontal cortex synaptic transmission: functional switch after chronic cocaine administration. J. Neurosci. 28, 529-542. doi: 10.1523/JNEUROSCI.2666072008

Ozono, R., O'Connell, D. P., Wang, Z. Q., Moore, A. F., Sanada, H., Felder, R. A., et al. (1997). Localization of the dopamine D1 receptor protein in the human heart and kidney. Hypertension 30 (3 Pt 2), 725-729. doi: 10.1161/ 01.HYP.30.3.725

Perrin, M., Donaldson, C., Chen, R., Blount, A., Berggren, T., Bilezikjian, L., et al. (1995). Identification of a second corticotropin-releasing factor receptor gene and characterization of a cDNA expressed in heart. Proc. Natl. Acad. Sci. U. S A. 92, 2969-2973. doi: 10.1073/pnas.92.72969

Rutz, C., Renner, A., Alken, M., Schulz, K., Beyermann, M., Wiesner, B., et al. (2006). The corticotropin-releasing factor receptor type 2 a contains an $\mathrm{N}$ terminal pseudo signal peptide. J. Biol. Chem. 281, 24910-24921. doi: 10.1074/ jbc.M601554200

Sanz, E., Monge, L., Fernández, N., Climent, B., Diéguez, G., and Garcia-Villalón, A. L. (2003). Mechanisms of relaxation by urocortin in renal arteries from male and female rats. Br. J. Pharmacol. 140, 1003-1007. doi: 10.1038/sj.bjp. 0705516

Schulz, K., Rutz, C., Westendorf, C., Ridelis, I., Vogelbein, S., Furkert, J., et al. (2010). The pseudo signal peptide of the corticotropin-releasing factor receptor type $2 \mathrm{a}$ decreases receptor expression and prevents Gi-mediated inhibition of adenylyl cyclase activity. J. Biol. Chem. 285, 32878-32887. doi: 10.1074/ jbc.M110.129627

Seeman, P., and Grigoriadis, D. (1987). Dopamine receptors in brain and periphery. Neurochem. Int. 10, 1-25. doi: 10.1016/0197-0186(87)90167-7

Slater, P. G., Yarur, H. E., and Gysling, K. (2016a). Corticotropin-releasing factor receptors and their interacting proteins: functional consequences. Mol. Pharmacol. 90, 627-632. doi: 10.1124/mol.116.104927

Slater, P. G., Cerda, C. A., Pereira, L. A., Andrés, M. E., and Gysling, K. (2016b). CRF binding protein facilitates the presence of CRF type $2 \alpha$ receptor on the cell surface. Proc. Natl. Acad. Sci. U. S. A. 113, 4075-4080. doi: 10.1073/ pnas. 1523745113

Snyder, K., Barry, M., and Valentino, R. (2015). Cognitive impact of social stress and coping strategy throughout development. Psychopharmacology 232, 185195. doi: $10.1007 / \mathrm{s} 00213-014-3654-7$

Takahashi, K. (2012). Distribution of urocortins and corticotropin-releasing factor receptors in the cardiovascular system. Int. J. Endocrinol. 2012, 395284. doi: $10.1155 / 2012 / 395284$

Teichmann, A., Rutz, C., Kreuchwig, A., Krause, G., Wiesner, B., and Schülein, R. (2012). The Pseudo signal peptide of the corticotropin-releasing factor receptor type 2A prevents receptor oligomerization. J. Biol. Chem. 287, 27265-27274. doi: 10.1074/jbc.M112.360594

Tezval, H., Jurk, S., Atschekzei, F., Becker, J. U., Jahn, O., Serth, J., et al. (2009). Urocortin and corticotropin-releasing factor receptor 2 in human renal cell carcinoma: disruption of an endogenous inhibitor of angiogenesis and proliferation. World J. Urol. 27, 825-830. doi: 10.1007/ s00345-009-0417-x

Tohgo, A., Choy, E. W., Gesty-Palmer, D., Pierce, K. L., Laporte, S., Oakley, R. H., et al. (2003). The stability of the G protein-coupled receptor-betaarrestin interaction determines the mechanism and functional consequence of ERK activation. J. Biol. Chem. 278, 6258-6267. doi: $10.1074 /$ jbc.M212231200 
Vale, W., Spiess, J., Rivier, C., and Rivier, J. (1981). Characterization of a 41residue ovine hypothalamic peptide that stimulates secretion of corticotropin and beta endorphine. Science 213, 1394-1397. doi: 10.1126/ science.6267699

Van Steensel, B., Van Binnendijk, E. P., Hornsby, C. D., Van der Voort, H. T., Krozowski, Z. S., de Kloet, E. R., et al. (1996). Partial colocalization of glucocorticoid and mineralocorticoid receptors in discrete compartments in nuclei of rat hippocampus neurons. J. Cell Sci. 109 (Pt 4), 787-792.

Yamaguchi, I., Jose, P. A., Mouradian, M. M., Canessa, L. M., Monsma, F. J. Jr., Sibley, D. R., et al. (1993). Expression of dopamine D1A receptor gene in proximal tubule of rat kidneys. Am. J. Physiol. 264 (2 Pt 2), F280-F285. doi: 10.1152/ajprenal.1993.264.2.F280
Conflict of Interest: The authors declare that the research was conducted in the absence of any commercial or financial relationships that could be construed as a potential conflict of interest.

The handling editor declared a past co-authorship with one of the authors [MA].

Copyright (c) 2020 Yarur, Andrés and Gysling. This is an open-access article distributed under the terms of the Creative Commons Attribution License (CC BY). The use, distribution or reproduction in other forums is permitted, provided the original author (s) and the copyright owner(s) are credited and that the original publication in this journal is cited, in accordance with accepted academic practice. No use, distribution or reproduction is permitted which does not comply with these terms. 